Deserter Country 
This page intentionally left blank 


\section{Deserter Country}

Civil War Opposition in the Pennsylvania Appalachians

Robert M. Sandow 


\section{Copyright () 2009 Fordham University Press}

All rights reserved. No part of this publication may be reproduced, stored in a retrieval system, or transmitted in any form or by any means-electronic, mechanical, photocopy, recording, or any other-except for brief quotations in printed reviews, without the prior permission of the publisher.

Fordham University Press has no responsibility for the persistence or accuracy of URLs for external or third-party Internet websites referred to in this publication and does not guarantee that any content on such websites is, or will remain, accurate or appropriate.

\section{Library of Congress Cataloging-in-Publication Data}

Sandow, Robert M.

Deserter country : Civil War opposition in the Pennsylvania Appalachians /

Robert M. Sandow.-1st ed.

p. cm.-(The North's Civil War)

Includes bibliographical references and index.

ISBN 978-0-8232-3051-8 (cloth : alk. paper)

1. Pennsylvania-History-Civil War, 1861-1865-Protest movements.

2. Pennsylvania-Politics and government-1861-1865. 3. Appalachians

(People)-Pennsylvania-History-19th century. 4. Appalachians

(People)-Pennsylvania-Politics and government-19th century. 5. United

States-History-Civil War, 1861-1865-Protest movements. 6. United

States-Politics and government-1861-1865. I. Title.

F153.S24 2009

$973.7^{\prime} 12097487$ - dc22

2008050384

Printed in the United States of America

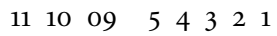

First edition 
For Miyuki and Mark 
This page intentionally left blank 